\title{
PENINGKATAN KEMAMPUAN INTERPRETASI ELECTROCARDIOGRAM (ECG) PERAWAT DENGAN PEMBELAJARAN PELATIHAN DAN MULTIMEDIA DI RSUD DR. SOERATNO SRAGEN
}

\author{
Akhmad Rifai, Dwi Sulistyowati \\ Kementerian Kesehatan Politeknik Kesehatan Surakarta Jurusan Keperawatan
}

\begin{abstract}
Level Of Ability Of Nurses, ECG Interpretation. American Heart Association (AHA) in 2011, recorded more then 1.000 .000 people have heart attacks every year, half died from the heart attack and in Europe figures reach 20,000-40,000 CHD patients than 1,000,000 population. In Indonesia in 2002 with acute myocardial infarction disease is the first cause of death with a mortality rate of 220,000 (14\%). The purpose of this study to determine the level of ability to interpret ECG nurse in RSUD $d r$. Soeratno Gemolong Sragen. This research is an experimental approach to Pre-TestPost Test Group design. through research hypothesis testing. The study population was a nurse amounted to 50 respondents divided into two groups. 30 respondents as the treatment group and 20 respondents as the control group. Statistical tests on the group in pairs using the nonparametric Wilcoxon test and unpaired pad groups using the Mann-Whitney test. Based on the results of the Wilcoxon test can be concluded that the 30 respondents who do the training interpretation of ECG by means of training and training using the modules can be drawn the conclusion that the majority of nurses had good knowledge in terms of ability to interpret ECG with $p$ value 0.001, which means there are significant differences between before and after doing the training. While the results of the Mann-Whitney test the difference between training and training in how to use the module $p$ value 0.001, which means there is a significant difference training by way of training and training in how to use the module.
\end{abstract}

Keywords: Level of ability of nurses, ECG Interpretation

Abstrak: Tingkat Kemampuan Perawat, Intepretasi ECG. American Heart Association (AHA) tahun 2011, mencatat lebih dari 1.000 .000 orang mengalami serangan jantung setiap tahun, setengahnya meninggal karena serangan jantung tersebut dan di Eropa angka penderita PJK mencapai 20.000-40.000 dari 1.000.000 penduduk. Negara Indonesia pada tahun 2002 penyakit infark miokard akut merupakan penyebab kematian pertama dengan angka mortalitas 220.000 (14\%). Tujuan penelitian ini untuk mengetahui tingkat kemampuan intepretasi ECG perawat di RSUD dr. Soeratno Gemolong Sragen. Penelitian ini merupakan penelitian eksperimental dengan pendekatan Pre-Tes-Post Test Group design. melalui pengujian hipotesa penelitian. Populasi penelitian ini adalah perawat berjumlah 50 responden yang terbagi menjadi dua kelompok. 30 responden sebagai kelompok perlakuan dan 20 responden sebagai kelompok kontrol. Uji statistik pada kelompok berpasangan menggunakan nonparametric Wilcoxon test dan pad kelompok yang tidak berpasangan menggunakan Mann-Whitney test. Berdasarkan hasil uji Wilcoxon dapat disimpulkan bahwa 30 responden yang dilakukan pelatihan intepretasi ECG dengan cara diklat maupun 
pelatihan menggunakan modul dapat ditarik simpulan bahwa mayoritas perawat memiliki pengetahuan yang baik dalam hal kemampuan intepretasi ECG dengan nilai $\mathrm{p}$ value 0,001 yang artinya ada perbedaan yang bermakan antara sebelum dan sesudah dilakukan pelatihan. Sedangkan hasil uji Mann-Whitney perbedaan antara pelatihan dengan cara diklat dan pelatihan dengan cara menggunakan modul nilai $\mathrm{p}$ value 0,001 yang artinya ada perbedaan yang bermakna pelatihan dengan cara diklat dan pelatihan dengan cara mengunakan modul.

Kata Kunci: Tingkat kemampuan perawat, Intepretasi ECG

\section{PENDAHULUAN}

Perubahan pola hidup masyarakat dan gaya hidup yang kurang sehat, penyakit kardiovaskuler (jantung dan pembuluh darah) adalah penyebab kematian yang utama di seluruh dunia. Kematian akibat penyakit jantung mengalami angka kejadian yang semakin tinggi. Penyakit ini menyerang penduduk di negara maju maupun negara berkembang (Santoso, 2005).

Meningkatnya angka kejadian penyakit jantung diperlukan pemeriksaan penunjang yang dapat membantu menegakkan diagnosa dengan tepat, sehingga dapat memberikan penanganan dan proses pengobatan dengan benar sesuai kondisi pasien. Electrocardiogram (ECG) adalah alat bantu diagnosis yang praktis, sederhana, akurat dan hasilnya dapat segera dibaca serta hampir semua kelainan dan kegawatdaruratan di bidang kardiovaskuler dapat dideteksi dengan ECG, sehingga seyogyanya semua petugas kesehatan, termasuk dokter umum, perawat, bahkan mahasiswa keperawatan harus mampu menguasai ECG (Dharma, 2010).American Heart Association (AHA) tahun 2011, mencatat lebih dari1.000.000 orang mengalami serangan jantung setiap tahun, setengahnya meninggal karena serangan jantung tersebut dan di Eropa angka penderita PJK mencapai 20.00040.000 dari 1.000.000 penduduk. Negara
Indonesia pada tahun 2002 penyakit infark miokard akut merupakan penyebab kematian pertama dengan angka mortalitas 220.000 (14\%).

Untuk mendukung keterampilan perawat dalam interpretasi ECG, maka banyak institusi dan organisasi kesehatan mengadakan berbagai pelatihan ECG. Pelatihan interpretasi ECG adalah pelatihan yang diberikan kepada peserta kursus dengan memberikan pendidikan dan pelatihan mengenai electrocardiography (Firdaus, 2009). RSUD dr. Soeratno Sragen merupakan rumah sakit daerah yang sedang berkembang. Ruang perawatan intensive belum bias maksimal untuk melakukan perawatan pasien kritis khususnya penyakit jantung, sehingga tenaga kesehatan khususnya perawat perlu meningkatkan pengetahuan dan ketrampilan dalam Penanganan pasien kritis, salah satunya adalah cara inteprestasi ECG.

\section{METODE PENELITIAN}

Penelitian ini merupakan
penelitian eksperimental dengan
pendekatan Pre-Tes-Post Test Group
design. melalui pengujian hipotesa
penelitian. Populasi penelitian ini adalah
perawat berjumlah 50 responden yang
terbagi menjadi dua kelompok. 30
responden sebagai kelompok perlakuan


dan 20 responden sebagai kelompok kontrol. Uji statistik pada kelompok berpasangan menggunakan nonparametric Wilcoxon test dan pad kelompok yang tidak berpasangan menggunakan MannWhitney test

\section{HASIL PENELITIAN}

Pengambilan data dilaksanakan pada bulan Juli 2016. Dari total 30 responden kelompok perlakuan dan 20 kelompok control yang direncanakan di RSUD Dr. Soeratno Gemolong Sragen, didapatkan hasil pre test dan post test baik pada kelompok perlakuan maupun pada kelompok kontrol dapat digambarkan dalam bentuk table distribusi frekwensi sebagai berikut:

a. Analisis Univariat

1. Diskripsi Karakteristik Responden

a) Karakteristik Responden

Berdasarkan Jenis Kelamin

Tabel 1

Distribusi Frekuensi Jenis Kelamin

Responden pada kelompok perlakuan

\begin{tabular}{llll}
\hline No & JenisKelamin & Frekuensi & $(\%)$ \\
\hline 1 & Laki - laki & 7 & 22,6 \\
2 & Perempuan & 23 & 74,2 \\
\hline & Jumlah & 30 & 100.0 \\
\hline
\end{tabular}

Tabel diatas menyajikan dari 30

responden, responden laki-laki berjumlah 7 orang $(22,6 \%)$ dan perempuan sebesar 23 orang $(74,2 \%)$. Sehingga mayoraitas responden adalah berjenis kelamin perempuan.

Tabel 2

Distribusi Frekuensi Jenis Kelamin Responden pada kelompok kontrol

\begin{tabular}{llll}
\hline No & JenisKelamin & Frekuensi & $(\%)$ \\
\hline 1 & Laki - laki & 4 & 20.0 \\
2 & Perempuan & 16 & 80.0 \\
\hline & Jumlah & 20 & 100.0 \\
\hline
\end{tabular}

Berdasarkan tabel diatas dari 20 responden, respon den laki-laki yaitu 4 orang $(20 \%)$ dan perempuan sebesar 16 orang $(80 \%)$. Sebagian besar pada kelompok control responder berjenis kelamin perempuan

b) Tingkat Kemampuan inteprestasi Ekg sebelum dan sesudah pelatihan pada kelompok Perlakuan dan kelompok kontrol

Hasil dari 30 responden, dengan tingkat intepretasi EKG pada kelompok Pelatiahan sebelum pelatihan baik 4 responden $(12,9 \%)$ Cukup 19 responden $(61 \%)$ Kurang 7 responden $(22,6 \%)$ dan hasil sesudah dilakukan pelatihan dengan hasil baik 24 responden $(77,4 \%)$ cukup 6 responden $(19,4 \%)$ sedangkan hasil pada pelatihan dengan menggunakan multimedia (modul) dengan 20 responden sebelum perlakuan dengan hasil baik 1 responden (5\%) cukup 10 responden $(50 \%)$ dan kurang 9 responden $(45 \%)$ sedangkan setelah dilakukan pelatihan menggunakan modul dengan hasil baik 5 responden $(25 \%)$ dan cucuk 15 responden $(75 \%)$

b. Analisis Bivariat

Tabel 3

Hasil analisis uji Willcoxon tingkat kemampuan intepretasi EKG Sebelum dan Sesudah dilakukan pelatihan pada Kelompok perlakuan

\begin{tabular}{|c|c|c|c|c|}
\hline Variabel & $\mathrm{N}$ & $\begin{array}{c}\text { Media } \\
\mathrm{n}\end{array}$ & $\begin{array}{c}\text { Rang } \\
\mathrm{e}\end{array}$ & $p$ \\
\hline $\begin{array}{l}\text { Tingkat } \\
\text { kemampuan } \\
\text { intepretasi EKG } \\
\text { sebelum } \\
\text { perlakuan }\end{array}$ & 30 & 3 & $2-4$ & 0,00 \\
\hline $\begin{array}{l}\text { Tingkat } \\
\text { kemampuan } \\
\text { intepretasi EKG } \\
\text { sesudah } \\
\text { perlakuan }\end{array}$ & 30 & 4 & $3-4$ & 1 \\
\hline
\end{tabular}




\begin{abstract}
Berdasarkan tabel diatas dari 30 responden, Tingkat kemampuan intepretasi EKG sebelum perlakuan dengan hasil median 3 dan range 2-4 sedangkan pada Tingkat kemampuan intepretasi EKG sesudah perlakuan dengan hasil median 4 dan range 3-4. Adapun hasil dari $\mathrm{P}$ value 0,001 yang artinya ada perbedaan antara sebelum dan sesudah dilakukan pelatihan EKG
\end{abstract}

\section{Tabel 4}

Hasil analisis uji Willcoxon tingkat kemampuan intepretasi EKG Sebelum dan Sesudah dilakukan pelatihan pada Kelompok kontrol

\begin{tabular}{lcccc}
\hline Variabel & $\mathrm{N}$ & $\begin{array}{l}\text { Media } \\
\mathrm{n}\end{array}$ & $\begin{array}{l}\text { Rang } \\
\mathrm{e}\end{array}$ & $p$ \\
\hline $\begin{array}{l}\text { Tingkat } \\
\text { kemampuan } \\
\text { intepretasi }\end{array}$ & 20 & 3 & $2-4$ & \\
$\begin{array}{l}\text { EKG sebelum } \\
\text { perlakuan }\end{array}$ & & & & 0,00 \\
$\begin{array}{l}\text { Tingkat } \\
\text { kemampuan } \\
\text { intepretasi } \\
\begin{array}{l}\text { EKG sesudah } \\
\text { perlakuan }\end{array}\end{array}$ & 20 & 3 & $3-4$ & 1 \\
\hline
\end{tabular}

Berdasarkan diatas, dari 20 responden, Tingkat kemampuan intepretasi EKG sebelum perlakuan dengan hasil median 3 dan range 2-4 sedangkan pada Tingkat kemampuan intepretasi EKG sesudah perlakuan dengan hasil median 3 dan range 3-4. Adapun hasil dari $P$ value 0,001 yang artinya ada perbedaan antara sebelum dan sesudah dilakukan pelatihan EKG dengan menggunakan modul

Tabel 5

Hasil analisis uji Mann-Whitney tingkat kemampuan intepretasi EKG kelompok Perlakukan dan Kelompok Kontrol sesudah pelatihan

\begin{tabular}{lcccc}
\hline Variabel & $\mathrm{N}$ & $\begin{array}{c}\text { Media } \\
\mathrm{n}\end{array}$ & Range & $p$ \\
\hline $\begin{array}{l}\text { Tingkat } \\
\text { kemampuan } \\
\text { intepretasi }\end{array}$ & 30 & 4 & $3-4$ & \\
$\begin{array}{l}\text { EKG } \\
\text { perlakuan }\end{array}$ & & & & \\
$\begin{array}{l}\text { Tingkat } \\
\text { kemampuan } \\
\text { intepretasi }\end{array}$ & 20 & 3 & $2-4$ & \\
$\begin{array}{l}\text { EKG } \\
\text { kontrol }\end{array}$ & & & & \\
\hline \multicolumn{1}{c}{ Tabel diatas menyajikan hasil }
\end{tabular}
analisis uji Mann-Whitney terdiri dari 30 responden tiap kelompok, median intervensi dan kontrol 30 dan 20, dengan range 23-4 dan 2-4, dan nilai $p=0,001$ sehingga dapat disimpulkan bahwa ada perbedaan yang bermakna antara kelompok intervensi dan kelompok kontrol sesudah dilakukan pelatihan Intepretasi EKG.

\section{PEMBAHASAN}

Hasil uji hipotesis menggunakan uji non parametric Wilcoxon, Tingkat kemampuan intepretasi EKG dengan nilai $\mathrm{p}=0,001$ pada kelompok intervensi dan hasil uji non parametric Wilcoxon pada kelompok kontrol nilai $\mathrm{p}=0,001$ yang berarti bahwa kedua kelompok intervensi dan kelompok kontrol sama-sama ada perbedaan yang bermakna terhadap Tingkat kemampuan intepretasi EKG.

Hasil uji tidak berpasangan (Mann-Whitney Test ) Tingkat kemampuan intepretasi EKG $\mathrm{p}=0,001$, hasil uji independen tersebut dapat di simpulakan bahwa ada perbedaan yang bermakna antara kelompok intervensi dan kelompok kontrol terhadap perubahan Tingkat kemampuan intepretasi EKG pada perawat.

Terdapat kesesuaian dengan penelitian Lusilawati (2012) yang berjudul "Pengaruh Pelatihan ECG Terhadap 
Keterampilan Perawat Dalam Menilai Hasil ECG Pasien Acute Coronary Syndrome (ACS)". Serta penelitian Susilawati (2011) yang berjudul "Pengaruh Pemberian Penyegaran Pelatihan ECG Terhadap Pengetahuan Perawat tentang Interpretasi ECG". Dengan adanya pelatihan dan pemberian materi ECG, terjadi peningkatan kemampuan interpretasi ECG pada perawat. Dengan menggunakan metode group learning hasil yang didapatkan lebih signifikan dan efektif terhadap kemampuan interpretasi ECG.

Selain itu, didapatkan juga hasil samping, pada 30 responden kelompok perlakuan yang menggunakan group learning, 10 orang $(33,3 \%)$ berada pada tingkat kemampuan baik, 15 orang yang berada pada tingkat kemampuan cukup naik 50\% menjadi tingkat kemampuan baik dan 5 orang pada tingkat kemampuan kurang naik $(16,7 \%)$ menjadi tingkat kemampuan baik. Jadi semua responden kelompok perlakuan menjadi $100 \%$ berada pada kategori tingkat kemampuan baik.

Pada 20 responden pada kelompok kontrol, responden pada kategori tingkat kemampuan baik, dari $5 \%$ naik $25 \%$, dan masih ada responden yang berada pada tingkat kemampuan cukup sebanyak 15 orang $(75 \%)$. Hal ini menunjukkan, samasama terjadi peningkatan kemampuan pada kedua kelompok, namun pada kelompok perlakuan, semua responden bisa $90 \%$ berada pada kategori tingkat kemampuan baik. Dengan adanya hal tersebut, diperlukan adanya penelitian lebih lanjut untuk meneliti metode pembelajaran yang paling efektif digunakan untuk menyampaikan materi interpretasi EKG.

\section{KESIMPULAN DAN SARAN}

1. Tingkat kemampuan intepretasi EKG Sesudah diberikan materi menggnakan pelatihan (Diklat) tentang interpretasi ECG mayoritas mempunyai tingkat kemampuan yang baik.

2. Tingkat kemampuan intepretasi $\mathrm{EKG}$ Sesudah diberikan materi menggnakan modul tentang interpretasi ECG mayoritas mempunyai tingkat kemampuan yang cukup.

3. Ada perbedaan yang signifikan antara metode pelatihan (diklat) dan pelatihan menggunakan modul terhadap tingkat kemampuan interpretasi ECG pada pada tenaga perawat di RSUD Gemolong Sragen Tahun 2016.

4. Metode pelatihan (diklat) dapat lebih dikembangkan dalam setiap institusi Rumah sakit, sehingga para tenaga kesehatan kususnya perawat dapat meningkatkan pengetahuan

5. Bagi peneliti selanjutnya yang berminat untuk melakukan penelitian yang serupa di harapkan dapat melakukan penelitian yang lebih kompleks.

\section{DAFTAR RUJUKAN}

Firdaus.(2009). Elektrokardiografi Praktis Tentang Kegawatan Jantung. Jakarta : Perki Jaya.

Lusilawati.(2012). Pengaruh Pelatihan EKG Terhadap Keterampilan Perawat Menilai Hasil EKG Pasien Acute Coronary Syndrome (ACS) Di Klinik Utama Jantung Cinere Depok. Available at http://www.library.upnvj.ac.id/pdf. (Diakses 25 Desember 2013).

Sugiyono. (2010). Metode Penelitian Kualitatif, Kuantitatif dan R\&D. Bandung : Alfabeta. 
18 Jurnal Terpadu Ilmu Kesehatan, Volume 6, No 1,Mei 2016, hlm 01-117

Sumiarty, C. (2008). Cara Praktis Membaca EKG. Jakarta : Surya Gemilang.

Sundana.(2008).Pedoman Interpretasi EKG Untuk Perawat.Jakarta : EGC.

Smeltzer, S.C., Bare, B.G.(2002).MedicalSurgical Nursing Brunner \& Suddarth 5th Ed. Philadelpia : W.B. Sounders. 